\title{
A 2-year survey of phytoplankton in the Marne Reservoir (France): A case study to validate the use of an in situ spectrofluorometer by comparison with algal taxonomy and chlorophyll a measurements
}

\author{
A. Rolland ${ }^{(1)}$, F. Rimet ${ }^{(1)}$, S. Jacquet ${ }^{(1)}$ \\ Received October 9, 2009 / Reçu le 9 octobre 2009 \\ Revised July 8, 2010 / Révisé le 8 juillet 2010 \\ Accepted July 16, 2010 / Accepté le 16 juillet 2010
}

\section{ABSTRACT}

Key-words: phytoplankton, chlorophyll a, taxonomy, bbe Fluoroprobe ${ }^{\mathrm{TM}}$, monitoring, reservoir
For almost two years (2006-2007), phytoplankton structure and distribution were monitored using a combination of methods in the Marne Reservoir (France). We used the bbe Fluoroprobe ${ }^{\mathrm{TM}}$ spectrofluorometer, which provides vertical profiles for different algal classes and chlorophyll analysis, based on the in vivo autofluorescence characteristics of the phytoplankton. In parallel, we measured chlorophyll a (chl a) concentrations using the classical extraction method coupled with spectrophotometric analyses, and calculated the biovolume of all the taxa identified using inverted light microscopy. A very close correlation $(\rho=0.93, n=243$, $p<0.0001$ ) was found between the total equivalent chl a concentrations given by the bbe Fluoroprobe ${ }^{\mathrm{TM}}$ and the total chl a concentrations $\left(\mu \mathrm{g} \cdot \mathrm{L}^{-1}\right)$ provided by the spectrophotometric analysis. The closest correlation was obtained for concentrations below $6.9 \mu \mathrm{g} \cdot \mathrm{L}^{-1}$ whereas little or no correlation was found for those above $21.6 \mu \mathrm{g} \cdot \mathrm{L}^{-1}$. The relationship was highly significant when total phytoplankton biovolume was compared with data from the probe $(\rho=0.6, n=243, p<0.0001)$, the strongest correlation being found for the group composed of diatoms, dinoflagellates and chrysophyceae $(\rho=0.67, p<0.0001)$, while the weakest relationship was for the blue-green cyanobacteria $(\rho=0.33, p<0.0001)$, although it was still highly significant. Our analysis, based on a large dataset, indicates that the Fluoroprobe ${ }^{\mathrm{TM}}$ appears to be a reliable tool suitable for use by fresh water managers to monitor phytoplankton on any relevant time and space scales.

\section{RÉSUMÉ}

Deux années de suivi du phytoplancton du réservoir Marne (France) : Étude de cas afin de valider l'utilisation d'un spectrofluorimètre de terrain par comparaison avec de la taxonomie et des mesures de chlorophylle a

\begin{abstract}
Mots-clés : phytoplancton, chlorophylle a, taxonomie, sonde bbe Fluoroprobe ${ }^{\mathrm{TM}}$, monitoring, réservoir

La structure et la distribution du phytoplancton dans le réservoir Marne ont été étudiées par différentes méthodes sur la période 2006-2007. Nous avons utilisé la sonde immergeable spectrofluorimétrique bbe Fluoroprobe ${ }^{\mathrm{TM}}$, qui fournit des profils verticaux de différents groupes d'algues et l'analyse de la chlorophylle a, grâce aux propriétés d'autofluorescence des cellules algales. Parallèlement, la concentration de la chlorophylle a a été mesurée par la méthode classique d'extraction pigmentaire et d'analyse spectrophotométrique, et nous avons calculé le biovolume de tous les taxons identifiés par microscopie. Une très bonne corrélation
\end{abstract}


$(\rho=0,93 ; n=243 ; p<0,0001)$ a été trouvée entre les concentrations en chlorophylle $a$ totales équivalentes fournies par la sonde bbe Fluororobe ${ }^{\mathrm{TM}}$ et les concentrations totales mesurées classiquement. La corrélation la plus élevée était trouvée pour des concentrations n'excédant pas $6,9 \mu \mathrm{g} \cdot \mathrm{L}^{-1}$ alors qu'elle était faible ou non significative pour des concentrations supérieures à $21,6 \mu \mathrm{g} \cdot \mathrm{L}^{-1}$. La relation était hautement significative quand le biovolume phytoplanctonique total était comparé avec les données de la sonde $(\rho=0,6 ; n=243 ; p<0,0001)$, la corrélation la plus forte étant pour le groupe des diatomées, dinoflagellés et chrysophycées $(\rho=0,67 ; p<0,0001)$, la plus faible étant celle pour les cyanobactéries bleues-vertes $(\rho=0,33 ; p<0,0001)$ bien qu'encore hautement significative. Notre analyse, réalisée à partir d'un grand nombre de données, semble indiquer que la sonde bbe Fluroroprobe ${ }^{\mathrm{TM}}$ est un outil parfaitement adapté au monitoring du phytoplancton des eaux douces réalisé par les gestionnaires.

\section{INTRODUCTION}

Since the second half of the 20th century, many water bodies have suffered from eutrophication, which promotes microalgal (phytoplankton) proliferation and is caused by increasing nutrient pollution (especially with phosphorus), leading to severe deterioration of water quality (Sommer, 1983; Reynolds, 1984; Tilman et al., 1986). The aim of the European Water Framework Directive (WFD) (European Parliament, 2000) is to reduce eutrophication, which is of particular concern for water management and treatment, in order to reach what has been termed "good ecological status" by the year 2015. This concept is defined as restoring "the state of an ecosystem to a close approximation of its condition prior to disturbance where ecological damage is repaired. Both the structure and the functions of the ecosystem are recreated" (US National Research Council, 1992 in Higgs, 1997). Ecological quality is based on the status of the biological (phytoplankton, macroalgae, macrophytes, benthos and fishes), hydromorphological and physico-chemical quality parameters.

The phytoplankton biomass constitutes a bio-monitoring index of major importance for the ecological survey and understanding of hydrosystems, and it has been a required part of the estimation of water quality for many decades (CIPEL, 1984; Brettum, 1989; Dokulil et al., 2005; Wolfram et al., 2007). In addition, chlorophyll a measurements have also been shown to provide a good estimate of phytoplankton biomass (Smayda, 1978; Harris, 1986; Wetzel and Likens, 2000). However, recent studies have shown that there are some problems with using the direct estimation of chlorophyll a (chl a) to deduce phytoplankton biomass, because spatial and temporal variations can occur on very short scales (Felip and Catalan, 2000), and the ratio of chl a to cell carbon depends on external and internal factors, such as phytoplanktonic taxonomy composition, cell physiological conditions, temperature, nutrient concentrations and light intensity. Phytoplankton biomass, via the estimation of chl a concentration, has also been used to obtain an indication of the trophic status of the water system (Vollenweider and Kerekes, 1982). The WFD therefore decided to include both the chl a concentration and the phytoplankton biovolume as two of the estimators used to define the ecological state of a lake (European Commission, 2008), even though it was recently suggested that the proportions of the different algal classes should also be considered to give an indication of the trophic status of the ecosystem (Reynolds et al., 2002) and furthermore, that taxon specificity must be assessed to provide a precise estimate of the trophic status of a lake (Anneville et al., 2002). Different techniques, materials and methods have become available for surveying phytoplankton development, from species identification and counts using microscopy (Utermöhl, 1958) to satellite images on a larger spatial scale (Allee and Johnson, 1999). It is noteworthy, however, that phytoplankton identification and microscopy counts are known to be very time-consuming and labor-intensive. This is one of the reasons why conventional taxonomybased surveys have generally been limited in scale and duration. Also, the Utermohl technique is not suited to measuring both eukaryotic and prokaryotic picoplankton $(<2 \mu \mathrm{m})$ which can, however, represent a significant chl a component (e.g. 30\%) in some oligotrophic 
and mesotrophic lakes. Here, fluorimetric techniques (typically epi-fluorescence microscopy) or flow cytometry are required. Satellite images are not suitable for surveying restricted areas, and provide only partial information (i.e. for the water near the surface). As a compromise, many in situ sensors providing immediate information have been developed to facilitate monitoring for water managers; these include fluorometers (Desiderio et al., 1997), and devices such as flow cytometers that can be deployed on moored systems (Thyssen et al., 2008). Beutler et al. (2002) designed a multi-wavelength probe, the bbe Fluoroprobe ${ }^{T M}$ (bbeMoldaenke, Kiel, Germany), which is a submersible spectrofluorometer that can operate down to a depth of $100 \mathrm{~m}$, and provides automatic algal class and chlorophyll analysis, based on the in vivo autofluorescence characteristics of pigment-containing micro-organisms, such as cyanobacteria and eukaryotic microalgae. Such a device provides a measurement of total equivalent chl a fluorescence, which is a commonly-used, reliable proxy for total phytoplankton biomass. The main advantage of the bbe Fluoroprobe ${ }^{\mathrm{TM}}$ is that it can cope with the constraints associated with water monitoring, such as the need for immediacy of response, low maintenance costs, specificity, sensitivity, ease of handling and rapidity of interpretation. Various algal groups can be identified by detecting diagnostic marker pigments, known as accessory pigments, typically by using high performance liquid chromatography or hyperspectral absorption curves. These marker pigments include peridinin (a marker for dinoflagellates or Pyrrophyta), chlorophyll $b$ (an indicator of green algae mainly), fucoxanthin (a diatom marker) and zeaxanthin, as well as phycobiliproteins (indicators of cyanobacteria and cryptophyceae) (Wright and Jeffrey, 1987; Moline and Prezelin, 1997; Moline et al., 1997a, 1997b; Trees et al., 2000; Millie et al., 2002).

To the best of our knowledge, only one study has so far attempted to confirm the quality of the whole dataset provided by this device over time and space (Gregor et al., 2005). Gregor and Maršalek (2004) had suggested earlier that the device could be recommended as a sensitive tool for water managers, but only for total equivalent chl a measurements. Both the studies mentioned above were performed on a relatively small number of samples. Leboulanger et al. (2002) successfully configured the bbe Fluoroprobe ${ }^{\mathrm{TM}}$, adding a specific fingerprint, and calibrated using both in situ populations during a mono-specific bloom and cultures to detect and quantify the PE (phycoeryhtrin)-rich cyanobacterium Planktothrix rubescens bloom on Lake Bourget (France). Note that the device is still used to survey the water quality of this large and deep peri-alpine lake and a reliably good correlation is found between $P$. rubescens counts and the bbe Fluoroprobe ${ }^{T M}$ (Jacquet et al. , 2008). Finally, Pinel-alloul et al. (unpublished data), also using a bbe Fluoroprobe ${ }^{\mathrm{TM}}$, described the formation and summer maintenance of deep chlorophyll maxima in Canadian oligotrophic lakes with different watershed land uses. Clearly, data are not yet available about the in situ application and accuracy of such a device with regard to all the microalgal groups that it can detect and over lengthy periods of time (i.e. for several successive seasons).

The aim of our study was therefore to compare and validate over a 2-year period the data obtained with the bbe Fluoroprobe ${ }^{\mathrm{TM}}$ with: (i) the total chl a concentrations provided by classical spectrophotometric measurements following pigment extraction; (ii) the total phytoplankton biovolume obtained after cell counts, and as estimated by the different formulae proposed by Hillebrand et al. (1999) and finally; (iii) the biovolume of the different phytoplankton classes identified after microscopic analyses.

\section{MATERIALS AND METHODS}

\section{$>$ SITE DESCRIPTION}

The Marne Reservoir (Figure 1) is one of the largest reservoirs in Western Europe $\left(48 \mathrm{~km}^{2}\right)$. It is situated in the Champagne region, $200 \mathrm{~km}$ east of the Paris Basin (France). It is subdivided into two shallow artificial "lakes": the smaller lake (Champaubert Lake, $0.5 \mathrm{~km}^{2}$, mean depth 3.5-4.5 m), which was completed in 1938, receives water from the Marne and Blaise rivers, whereas water is released from the larger one (Der Lake, $47.5 \mathrm{~km}^{2}$, mean depth 7-9 m). 


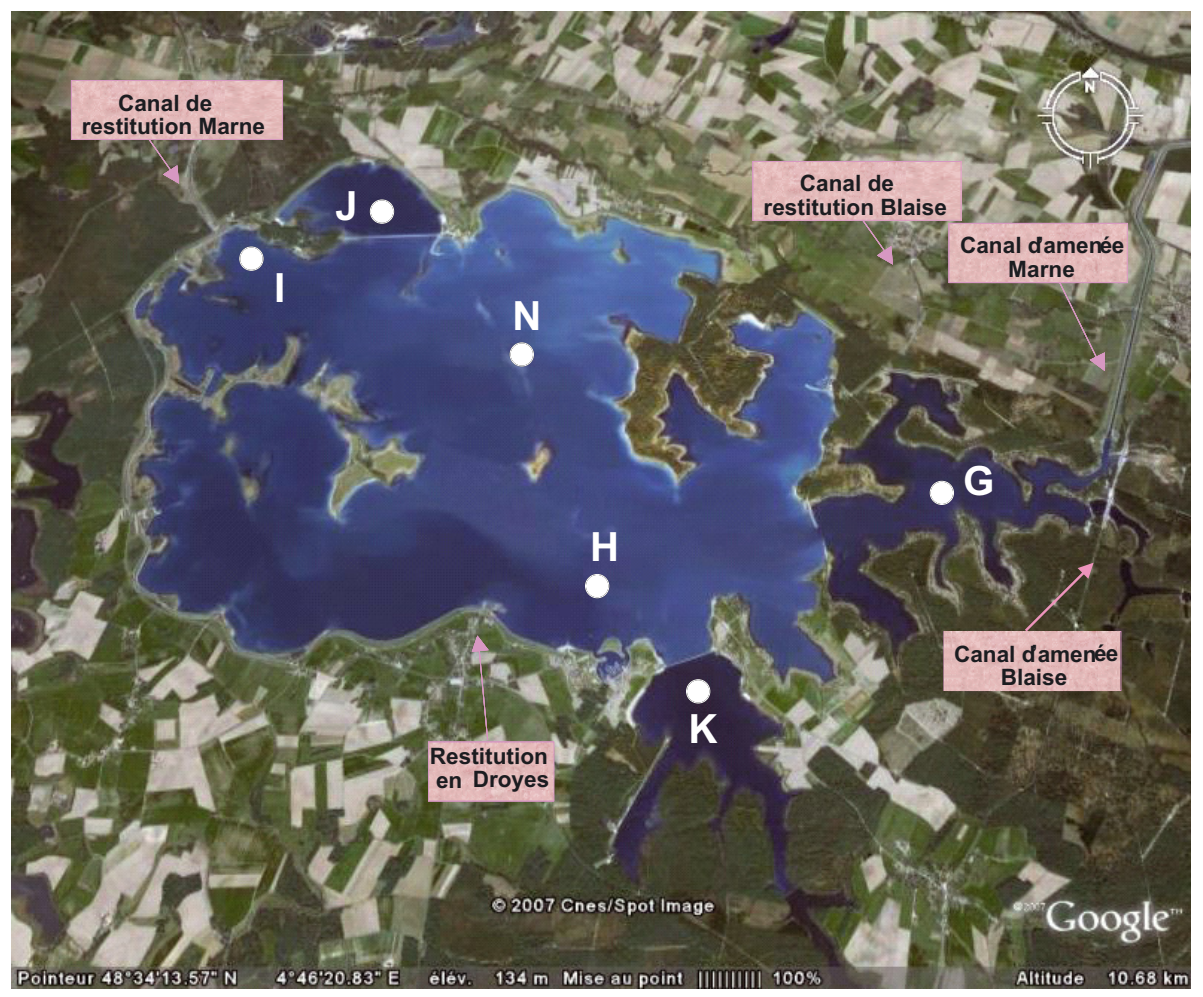

Figure 1

Map of the Marne Reservoir with its two main basins (lake Der and lake Champaubert) and localization of the sampling stations $H$ (station Giffaumont), I (tour de restitution), N (lac du der), G (lac de Champaubert), $K$ (bassin sud-est), J (bassin nord-ouest) (image from Google earth, 2008).

Figure 1

Image Google earth du Réservoir Marne permettant d'observer ses deux principaux bassins (le lac du Der et le lac Champaubert) et la localisation des sites d'échantillonnage : H (station Giffaumont), I (tour de restitution), N (lac du der), G (lac de Champaubert), K (bassin sud-est), J (bassin nord-ouest).

This large reservoir was completed in 1974 and is intended to prevent flooding of Paris during winter and early spring, and to enhance low flows in summer. The water level varies between 2 and $15 \mathrm{~m}$ over the hydrological cycle, with water volume being greatest in summer (July) and lowest in late fall (November). Depending on summer weather conditions (wind, temperature) and management strategies, the water column may be stratified for a few weeks in summer, and the water residence time varies between approximately 3 and 12 months. The reservoir is classed as a mesotrophic water body, with annual mean concentrations of total phosphorus of about $15 \mu \mathrm{g} \cdot \mathrm{L}^{-1}$, ranging from $8 \mu \mathrm{g} \cdot \mathrm{L}^{-1}$ in winter to $32 \mu \mathrm{g} \cdot \mathrm{L}^{-1}$ in summer (Rolland and Jacquet, 2010).

\section{> SAMPLING STRATEGY}

The samples used for this study were collected every two to three weeks between March and September in 2006 and 2007. Six different stations in the reservoir were investigated during each campaign. The Fluoroprobe ${ }^{\mathrm{TM}}$ was lowered down the water column in order to visualize the distribution of the microalgal biomass as a whole, and that of the different pigment classes that are related to phytoplankton classes in particular (see details below). Simultaneously, water samples were collected at specific depths $(3,6$ and $8 \mathrm{~m})$ using a Van Dorn sampling bottle. The water collected in the bottle was homogenized, and samples were separated for $\mathrm{chl}$ a extraction and quantification, and for species determination. For the latter, $100 \mathrm{~mL}$ were 
immediately fixed with Lugol's solution on board the ship. All samples were kept in the dark at between 4 and $6{ }^{\circ} \mathrm{C}$ until they reached the laboratory and underwent immediate processing.

\section{> FLUORESCENT-BASED METHOD}

Since 2002, a multi-wavelength submersible probe (FluoroProbe ${ }^{\mathrm{TM}}$, bbe-Moldaenke) has been available to scientists and water managers (Beutler et al., 2002). This device can differentiate between "spectral groups" of microalgae both in vivo and in situ, and provides vertical profiles (down to $100 \mathrm{~m}$ ) within a few minutes (e.g. Leboulanger et al., 2002), on the basis of the relative fluorescence intensity of chl $a$ at $680 \mathrm{~nm}$ (due to the photosystem II core pigments). The use of spectral fluorescence where multiple excitation and/or emission wavelengths are used to characterize taxonomic composition was recognized quite a long time ago as a promising technique because measurements could also be made in continuous mode (Yentsch and Yentsch, 1979). The spectral fluorescence is based on selective excitation of the differing antenna and accessory pigments between taxonomic groups of algae. This emission of fluorescence with the bbe Fluoroprobe ${ }^{\mathrm{TM}}$ follows sequential light excitation by 6 Light-Emitting Diodes (LEDs), which segregate the green group (chlorophyceae and euglenophyceae) $(450 \mathrm{~nm}$ ), the brown group (diatoms, chrysophyceae and dinoflagellates, or the Heterokontophyta and Pyrrophyta for the dinoflagellates) $(525 \mathrm{~nm})$, the phycoerythrincontaining (PE-rich) group (cryptophytes and red cyanobacteria) $(570 \mathrm{~nm})$, and the blue-green group (blue-green cyanobacteria) $(590$ and $610 \mathrm{~nm})$, respectively. The "brown" group have photosynthetic carotenoids, fucoxanthin or peridinin pigments for which absorbing wavelengths of light are poorly absorbed by the chlorophylls. The same can be said for the "bluegreen" and the "red" groups, characterized mainly by phycobilin accessory pigments (i.e. phycocyanin and phycoerythrin, respectively) that also absorb in a spectral region where it is minimal for chlorophylls. In other words, depending on the accessory pigments of the light-harvesting complexes, and thus on the phylogenetic position of the phytoplanktonic individuals present in the sample, a set of characteristic fingerprints can be detected. The UV LED $(370 \mathrm{~nm})$, which has been added to the latest generation of devices, is used to measure the fluorescence of colored dissolved organic matter (cDOM), which is referred to as "yellow substances". In our case, it allowed us to ascertain that water transparency was important and was unlikely to have a strong bearing on the ability of the device to differentiate among the various groupings of phytoplankton. It is noteworthy here that cDOM determination in the reservoir was not made, provided that the fairly good correlation between the total equivalent chlorophyll a fluorescence provided by the bbe Fluoroprobe ${ }^{\mathrm{TM}}$ and the real chlorophyll a concentration, measured after extraction (see results), suggested that cDOM influence was probably negligible and/or that the probe was already adequately calibrated for yellow substance concentrations present in the reservoir. Measurements were performed every $0.5 \mathrm{~s}$ from the surface down to $50 \mathrm{~cm}$ above the sediment at each of the sampling stations. This generated between 10 and 15 data for every meter of the water column. The values given by the Fluoroprobe ${ }^{\mathrm{TM}}$ were integrated, and averaged from 2.2 to $3 \mathrm{~m}, 5.2$ to $6 \mathrm{~m}$ and 7.2 to $8 \mathrm{~m}$ in order to make the data comparable with those from the Van Dorn sampling bottle, that is $80 \mathrm{~cm}$ long. We also compared the results obtained using a single depth (i.e. 3, 6 or $8 \mathrm{~m}$ ), and did not find any significant difference between the two approaches. The excitation spectrum obtained was then compared with normal standard curves stored in the probe. Dedicated software (Fluoroprobe 1.9, bbe Moldaenke) was then used to calculate the relative amounts of each of the phytoplankton spectral groups present, expressed in terms of the equivalent amount of chl a per liter of water (equiv. $\mu \mathrm{g} \mathrm{chl} a \cdot \mathrm{L}^{-1}$ ), and which reflects the recorded fluorescence values. Details about the design, functioning and data output of this software can be obtained directly from http://www.bbe-moldaenke.de/chlorophyll/fluoroprobe/. The data were transferred to a PC connected to the probe, which immediately displayed the results in tables and graphs (Beutler et al., 2002; Leboulanger et al., 2002; Gregor and Maršálek, 2004; Jacquet et al., 2005). 
The samples were first filtered throughout a $200-\mu \mathrm{m}$ mesh filter in order to remove large organisms (i.e. metazooplankton). Next, the chlorophyll was collected on a GF/F (nominal porosity: $0.7 \mu \mathrm{m}$ ) glass filter. The volume filtered varied from 0.5 to $1 \mathrm{~L}$, depending on the chl a concentrations provided by the Fluoroprobe ${ }^{\mathrm{TM}}$. Each filter was immersed for $5 \mathrm{~min}$ in $12 \mathrm{~mL}$ of $90 \%$ acetone that had previously been heated to $78-80^{\circ} \mathrm{C}$ to extract the pigment. The filters were kept in the dark at $4{ }^{\circ} \mathrm{C}$ for a period of $24 \mathrm{~h}$ to maximize extraction. They were then ground for $30 \mathrm{~s}$ to facilitate cell degradation. The extract was then filtered through a $45-\mu \mathrm{m}$ filter to eliminate the cellular constituents, and to collect the solvent containing the pigments. $\mathrm{Chl}$ a extracts were then measured spectrophotometrically, in a 4-cm-long cuvette at 750 and $665 \mathrm{~nm}$ before and after acidifying the sample with hydrochloric acid $(0.1 \mathrm{~mL}$ of $\mathrm{HCl} 0.1 \mathrm{~N})$. According to Lorenzen (1967), this corrects for interference due to the presence of phaeophytin (a chlorophyll decomposition product that absorbs at the same wavelength). Moreover, as we have already mentioned, a reading was also carried out at $750 \mathrm{~nm}$ to eliminate the absorbance due to turbidity. These values were subtracted from those obtained at $665 \mathrm{~nm}$. Calculations were done according to Lorenzen (1967). The AFNOR (Agence Française de Normalisation) standard (1999) provides a complete and detailed description of the procedure.

\section{>PHYTOPLANKTON ANALYSIS}

Phytoplankton identification and counts were performed with an inverted microscope (Zeiss Axiovert 135) following the Utermöhl procedure (Utermöhl, 1958; AFNOR, 2006). Algal, species were observed at high magnification $(\times 640)$ along both the diameters of the sedimentation chamber, and counted until at least 400 cells in each group had been identified. Species abundance was calculated taking into consideration the surface area of the 2 diameters counted, the surface area of the sedimentation chamber, and the volume of water sedimented. The biovolume (measured for each cell counted, and calculated for the total) was then estimated using the various formulae proposed by Hillebrand et al. (1999). The Fluoroprobe ${ }^{\mathrm{TM}}$ provides concentrations for the four pigment classes that can theoretically be assigned to four taxonomic phytoplankton classes: the "Greens" that include chlorophyceae and Desmidiates (CD), the "Blue-Greens" that consist of blue-green cyanobacteria (BGC), the "Browns" that consist of diatoms, dinoflagellates and chrysophyceae (DDC), and the "Reds" containing cryptophyceae and phycoerythrin-rich cyanobacteria (CRC).

\section{> DATA ANALYSIS AND STATISTICS}

As the distributions of the data were not normal even after logarithmic transformation, nonparametric Spearman rank correlations were used to identify the relationships between: (i) the total equivalent $\mathrm{chl}$ a provided by the bbe Fluoroprobe ${ }^{\mathrm{TM}}$ and the usual spectrophotometric measurements; (ii) the total equivalent chl a given by the bbe Fluoropobe ${ }^{\mathrm{TM}}$ and the total phytoplankton biovolume obtained by microscopy; and (iii) the pigment class chl a equivalents obtained by the bbe Fluoroprobe ${ }^{\mathrm{TM}}$ and phytoplankton class biovolumes. All the analyses were carried out using the statistical software Sigma Stat (Stat32). In order to provide an overall assessment of the correlations between the data provided by the fluoroprobe and the results given by the Utermöhl technique, a canonical correspondence analysis (CCA), i.e. a multivariate direct gradient analysis method aimed at looking at the relationships between two sets of variables (ter Braak, 1986, 1987), was computed using the PC-Ord software (McCune and Mefford, 2006). The biovolumes of the different algal groups (DDC, BGC, CD and CRC) obtained with the Utermöhl technique were used as a secondary matrix to explain the chlorophyll a results of the four algal groups obtained with the Fluoroprobe ${ }^{\mathrm{TM}}$ (main matrix). 


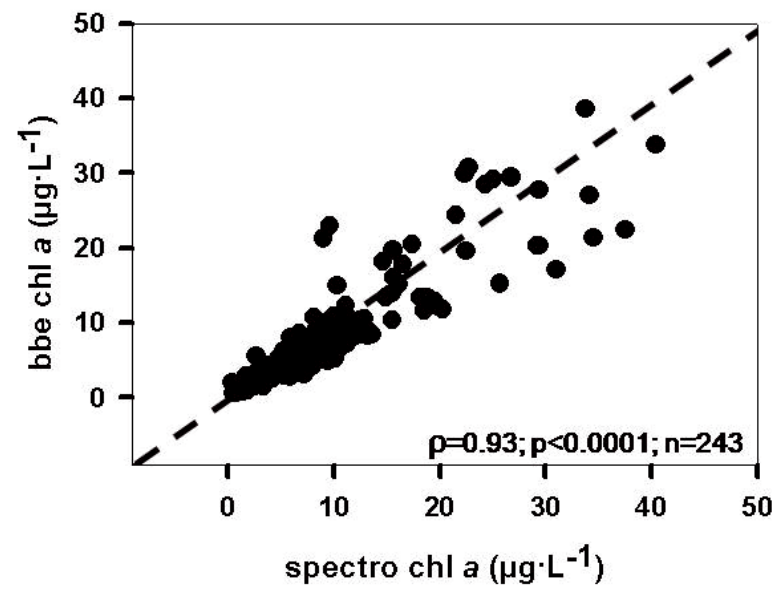

\section{Figure 2}

Relationship between total $\mathrm{chl}$ a concentrations $\left(\mu \mathrm{g} \cdot \mathrm{L}^{-1}\right)$ given by the bbe Fluoroprobe ${ }^{\mathrm{TM}}$ and those provided by the spectrophotometric analyses. The dashed line corresponds to a 1:1 relationship.

Figure 2

Relation entre les concentrations $\left(\mu \mathrm{g} \cdot \mathrm{L}^{-1}\right)$ en chl a totales obtenues par la sonde bbe Fluoroprobe $\mathrm{T}^{\mathrm{TM}}$ et celles fournies après analyse spectrophométrique. La ligne en pointillé symbolise la relation 1:1.

\section{RESULTS}

\section{> COMPARISON OF THE BBE FLUOROPROBE ${ }^{\mathrm{TM}}$ AND THE SPECTROPHOTO- METRIC ANALYSES FOR MEASURING TOTAL CHL A CONCENTRATIONS}

The dataset was obtained from the measurements made over the two sampling years (23 sampling dates) at six stations and three different depths $(3,6$ and $8 \mathrm{~m}$ ), where the water was deep enough to permit this. This yielded a total of $243 \mathrm{chl}$ a concentration measurements for this period, ranging from 0.5 to $38.6 \mu \mathrm{g} \cdot \mathrm{L}^{-1}$ for the bbe Fluoroprobe ${ }^{\mathrm{TM}}$ and from 0.1 to $40.4 \mu \mathrm{g} \mathrm{L}^{-1}$ for the spectrophotometric analyses. As shown by Figure 2, the relationship between the total equivalent chl a concentrations (i.e. the sum of the chlorophyll a concentrations from each spectral group) given by the bbe Fluoroprobe ${ }^{\mathrm{TM}}$ and the spectrophotometry was very strong $(\rho=0.93, p<0.0001)$. Moreover, when this relationship was analyzed for the different depths separately, we also obtained highly significant correlations between the chl a concentrations obtained by the two methods ( $3 \mathrm{~m}: \rho=0.94, p<0.0001, n=135 ; 6 \mathrm{~m}$ : $\rho=0.93, p<0.0001, n=68 ; 8 \mathrm{~m}: \rho=0.79, p<0.0001, n=40)$.

In order to assess the ecological potential of the Marne Reservoir in the context of the Water Framework Directive, the research institute for sustainable management of water and landscapes (i.e. the CEMAGREF) established a range of five water quality classes based on chl a concentrations (De Bortoli and Argillier, 2008): very good quality for chl a concentrations that are below or equal to $3.9 \mu \mathrm{g} \cdot \mathrm{L}^{-1}$, good, moderate and passable qualities for chl a concentrations comprised between 3.9 and $6.9 \mu \mathrm{g} \cdot \mathrm{L}^{-1}, 6.9$ and $12.2 \mu \mathrm{g} \cdot \mathrm{L}^{-1}$, and 12.2 and $21.6 \mu \mathrm{g} \cdot \mathrm{L}^{-1}$, respectively, and poor quality for chl a concentrations that are above $21.6 \mu \mathrm{g} \cdot \mathrm{L}^{-1}$. Data from our spectrophotometric analyses were assigned to these classes, and the associated fluorometric chl a concentrations were plotted to test whether the bbe Fluoroprobe ${ }^{\mathrm{TM}}$ was able to detect the different chl a concentrations accurately. As a result, we tested the relationship between each chl a concentration class established from spectrophotometric analysis and the chl a concentrations obtained by fluorometry (Figure 3). The first class, which included 61 observations, was significantly correlated with the fluorometric chl a concentrations $(\rho=0.66, p<0.0001$ ) (Figure 3a). The best correlation we found was between the second class of chl a concentrations given by the spectrophotometric analyses and the associated 

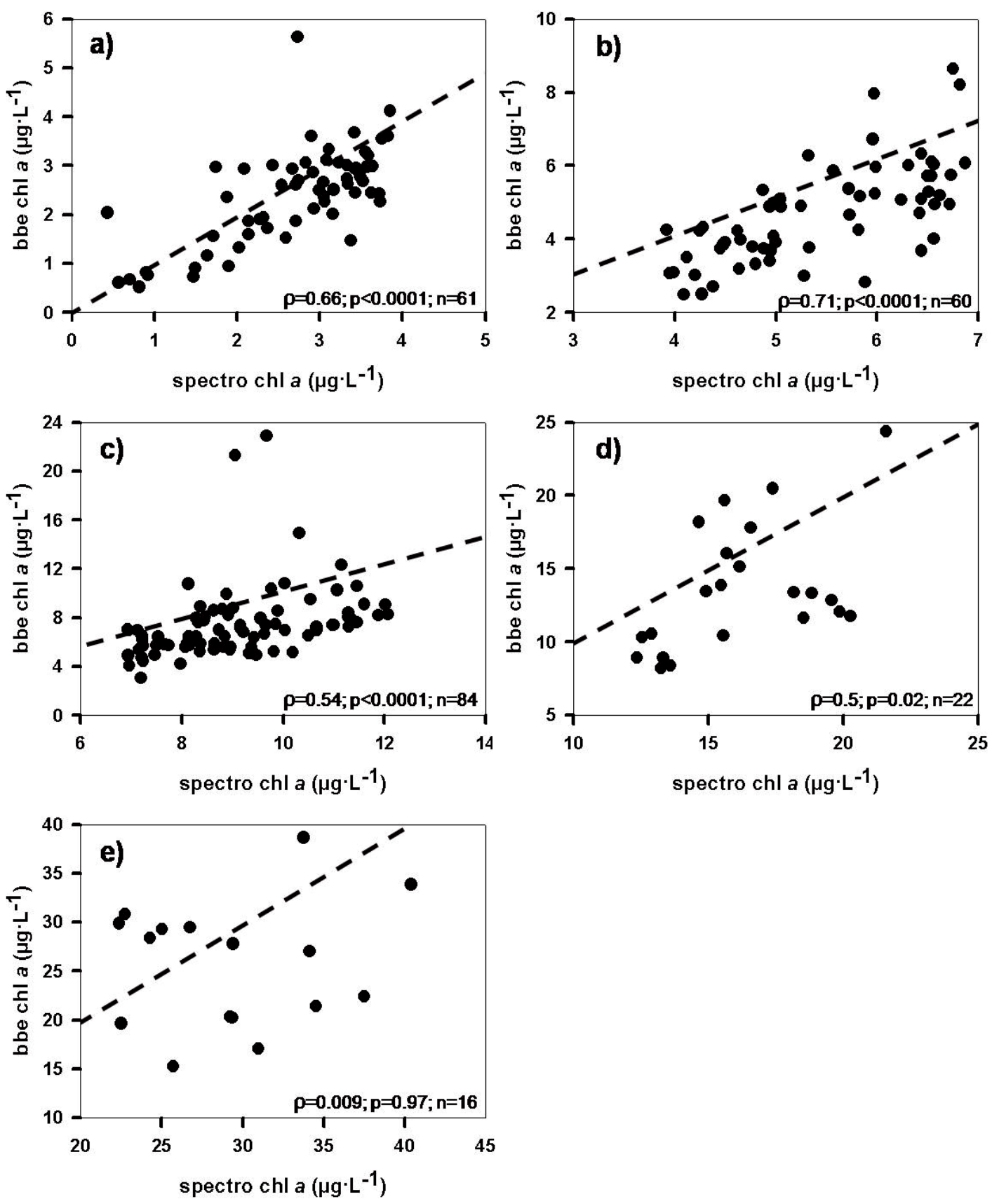

Figure 3

Relationships between total chl a concentrations $\left(\mu \mathrm{g} \cdot \mathrm{L}^{-1}\right)$ given by the Fluoroprobe ${ }^{\mathrm{TM}}$ and those provided by the spectrophotometric analyses subdivided into five concentration classes (as proposed by the CEMAGREF in the context of the WFD) i.e. a) $<4.6 \mu \mathrm{g} \cdot \mathrm{L}^{-1}$; b) $\left[4.6-8\left[\mu \mathrm{g} \cdot \mathrm{L}^{-1}\right.\right.$; c) $\left[8-12.2\left[\mu \mathrm{g} \cdot \mathrm{L}^{-1}\right.\right.$; d) $\left[12.2-21.6\left[\mu \mathrm{g} \cdot \mathrm{L}^{-1} ; \mathrm{e}\right) \geq 21.6 \mu \mathrm{g} \cdot \mathrm{L}^{-1}\right.$. The dashed line corresponds to a $1: 1$ relationship.

\section{Figure 3}

Relation entre les concentrations ( $\mathrm{ug} \cdot \mathrm{L}^{-1}$ ) en chl a totales obtenues par la sonde bbe Fluoroprobe ${ }^{\mathrm{TM}}$ et celles fournies après analyse spectrophométrique, subdivisées en cinq classes telles que proposées par le CEMAGREF, c'est-à-dire a) < 4,6 $\mu \mathrm{g} \cdot \mathrm{L}^{-1}$; b) $\left[4,6-8\left[\mu \mathrm{g} \cdot \mathrm{L}^{-1}\right.\right.$; c) $\left[8-12,2\left[\mu \mathrm{g} \cdot \mathrm{L}^{-1}\right.\right.$; d) $\left[12,2-21,6\left[\mu \mathrm{g} \cdot \mathrm{L}^{-1}\right.\right.$; e) $\geq 21,6 \mu \mathrm{g} \cdot \mathrm{L}^{-1}$. La ligne en pointillé symbolise la relation 1:1. 


\section{Table I}

Proportion of the spectrofluorometric chl a concentrations that fit into the spectrophotometric chl a concentration classes established by De Bortoli and Argillier (2008) of the research institute for sustainable management of water and landscapes (CEMAGREF).

\section{Tableau}

Correspondances entre les proportions de concentrations en chl a obtenues par spectrofluorimétrie et les classes de chl a obtenues par spectrophotométrie telles qu'établies par De Bortoli et Argillier (2008) du CEMAGREF.

\begin{tabular}{|c|c|c|c|c|c|}
\hline \multirow{2}{*}{$\begin{array}{l}\text { Chl a concentration classes } \\
\text { established by the CEMAGREF* } \\
\text { in the context of the WFD }\end{array}$} & \multicolumn{5}{|c|}{$\begin{array}{l}\text { Proportion of chl a concentrations obtained with the } \\
\text { Fluoroprobe }{ }^{\mathrm{TM}} \text { found in the CEMAGREF classes }\end{array}$} \\
\hline & $<3.9$ & {$[3.9-6.9$} & {$[6.9-12.2[$} & {$[12.2-21.6[$} & $\geq 21.6$ \\
\hline$<3.9$ & 0.97 & 0.03 & 0 & 0 & 0 \\
\hline [3.9-6.9] & 0.33 & 0.62 & 0.05 & 0 & 0 \\
\hline [6.9-12.2[ & 0 & 0.44 & 0.51 & 0.05 & 0 \\
\hline$[12.2-21.6$ & 0 & 0 & 0.45 & 0.50 & 0.05 \\
\hline$\geq 21.6$ & 0 & 0 & 0 & 0.38 & 0.62 \\
\hline
\end{tabular}

* Institut de recherche pour l'ingénierie de l'agriculture et de l'environnement.

bbe Fluoroprobe ${ }^{\mathrm{TM}}$ measurements $(\rho=0.71, p<0.0001, n=60)$ (Figure 3b). For the data included in the third class $(n=84)$, the Spearman correlation coefficient, linking chl a concentrations given by spectrophotometric analyses and those from the bbe Fluoroprobe ${ }^{\mathrm{TM}}$, was slightly lower although still highly significant $(\rho=0.54, p<0.0001)$ (Figure 3c). The fourth class, including chl a concentrations between 12.2 and $21.6 \mu \mathrm{g} \cdot \mathrm{L}^{-1}(n=22)$, still exhibited a strong relationship with the associated fluorometric measurements $(\rho=0.50, p=0.02)$ (Figure 3d). The weakest relationship was found for the highest concentrations: for concentrations above $21.6 \mu \mathrm{g} \cdot \mathrm{L}^{-1}(n=16)$, the correlation with the results given by the Fluoroprobe ${ }^{\mathrm{TM}}$ was weak, and the Spearman coefficient was nearly zero $(\rho=0.009, p=0.97$ ) (Figure 3e). Although $n$ was relatively small in the latter case, the relationships between the chl a concentrations obtained by the two methods was still valid. However, this does not tell us whether the concentration range was the same for both methods. Therefore, from the data obtained by spectrophometric analyses and used to determine the CEMAGREF water quality classes, we calculated the proportion of the Fluoroprobe ${ }^{T M} \mathrm{chl}$ a concentrations that could be fitted into these classes (Table I). If we look at the ranges of concentrations, all the values appear to be correlated; bbe-based fluorometry tends to suggest lower chl a concentrations than spectrophotometry, and we observed that on average the spectrophotometric data were indeed about 1.2 times higher than the bbe data (data not shown). This was not surprising, as extracted chlorophyll methods should (almost) always provide a higher concentration estimate than fluorescence or absorption measurements from living cells.

\section{> COMPARISON BETWEEN CHL A CONCENTRATIONS GIVEN BY THE BBE FLUOROPROBE ${ }^{\mathrm{TM}}$ AND PHYTOPLANKTON BIOVOLUME}

As chl a concentration is used as an estimation of phytoplankton biomass, the total equivalent chl a concentrations given by the Fluoroprobe ${ }^{\mathrm{TM}}$ and the total biovolume estimates obtained after microscopic counting were plotted and compared. For the whole dataset (Figure 4), the correlation between the two variables was highly significant $(\rho=0.6, p<0.0001, n=243$ ), but the correlation between the chl a concentrations and the total biovolume estimates was weaker, although still significant, for the spectrophotometric analyses.

The strength of the correlation between chl $a$ and biovolume depended on the algal class considered. The strongest correlation was found between the equivalent amount of chl a for the "Browns" and the biovolume of the Diatoms, Dinoflagellates and Chrysophyceae $(\rho=0.67, p<0.0001, n=242)$ (Figure 5a). The correlation between the amount of chl a for the "Reds" and the biovolume of the Cryptophyceae and PE-rich cyanobacteria was also 


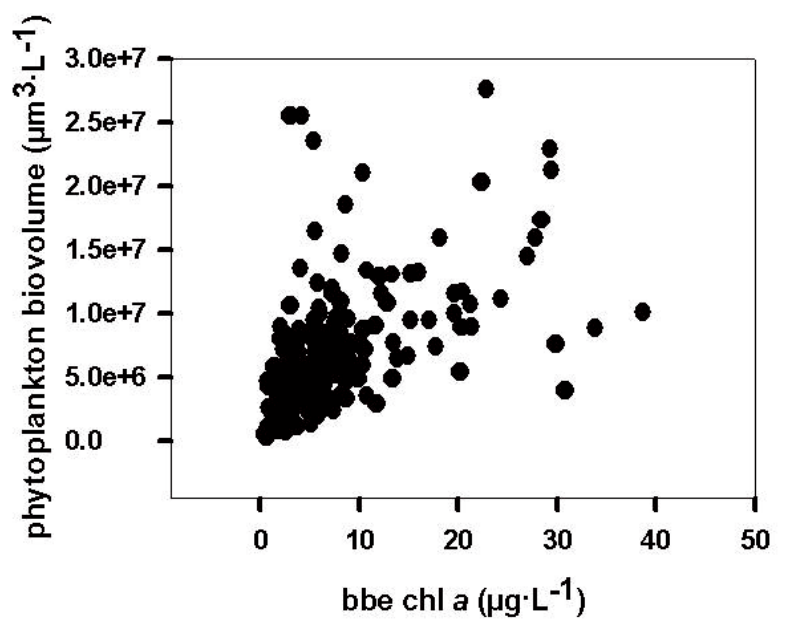

\section{Figure 4}

Relationship between the total phytoplankton biovolume $\left(\mu \mathrm{m}^{3} \cdot \mathrm{L}^{-1}\right)$ and total chl a concentrations $\left(\mu \mathrm{g} \cdot \mathrm{L}^{-1}\right)$ given by the Fluoroprobe ${ }^{\mathrm{TM}}$.

Figure 4

Relation entre le biovolume phytoplanctonique total $\left(\mu \mathrm{m}^{3} \cdot \mathrm{L}^{-1}\right)$ et les concentrations $\left(\mu \mathrm{g} \cdot \mathrm{L}^{-1}\right)$ en chl a totales obtenues avec la sonde Fluoroprobe ${ }^{\mathrm{TM}}$.

strong $(\rho=0.55, p<0.0001, n=242$ ) (Figure $5 b)$. Despite the highly significant relationship between the amount of chl a for the "Greens" and the biovolume of the Chlorophyceae $(p<0.0001)$, the Spearman correlation coefficient was lower $(\rho=0.46)$ (Figure $5 c)$, as was the correlation coefficient for the amount of chl a of the "Blue-Greens" and the biovolume of the Cyanobacteria $(\rho=0.33, p<0.0001$ ) (Figure $5 d$ ).

Figure 6 shows the results of the CCA, revealing that the overall explained variance on the two first axes was $56.3 \%$. The Utermöhl technique and the Fluoroprobe ${ }^{\mathrm{TM}}$ were correlated, since the biovolumes measured with the Utermöhl technique and the chl a measured with the Fluoroprobe ${ }^{T M}$ are in the same parts of the graph for the Browns/DDC, for the BlueGreens/BGC and for the Reds/CRC. The only algal class which did not show close correlation between the two techniques was the "Greens". As the length of the vectors refers to the strength of the correlations between the two techniques, we can see that the closest correlations were obtained for the "Blue-Greens" and the "Browns".

\section{DISCUSSION}

Our aim was to check the accuracy of the Fluoroprobe ${ }^{\mathrm{TM}}$ bbe spectrofluorometer using a large dataset covering a succession of different seasons in one large reservoir. We did this by the parallel use of a spectrophotometric method to quantify the total chl a concentration, and of light microscopy to assess phytoplankton diversity and biovolume. The only comparable previous studies were those done by Gregor and Maršálek (2004) and Gregor et al. (2005), but these authors used considerably fewer values and lower taxonomic resolution than we did.

\section{> DIFFERENCE BETWEEN SPECTROPHOTOMETRIC ANALYSES AND SPECTROFLUOROMETRIC MEASUREMENTS}

We found a strong and highly significant correlation between the spectrophotometric and spectrofluorometric determinations of the chl a concentrations, i.e. between the classical 

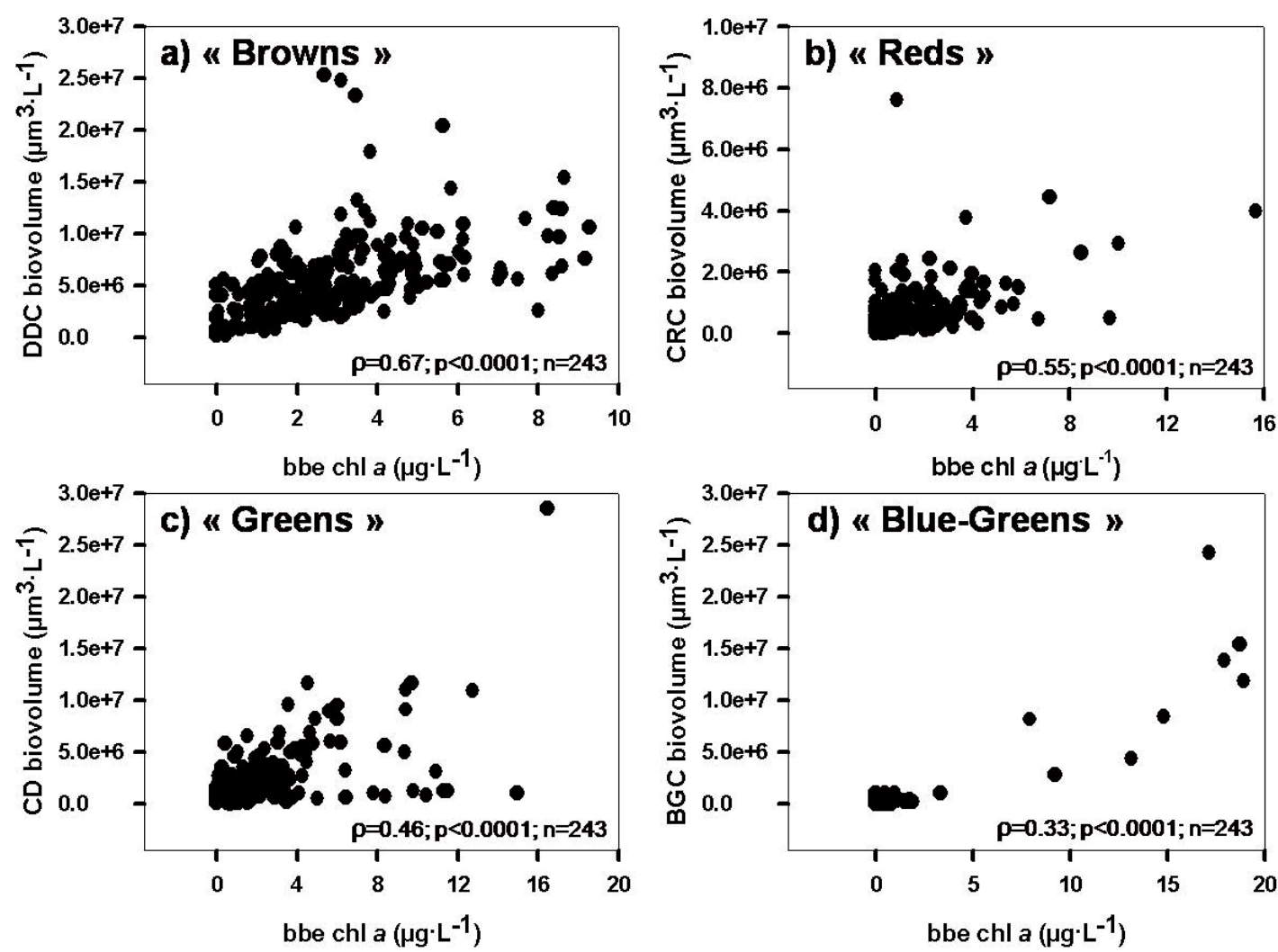

Figure 5

Relationships between the total $\mathrm{chl}$ a concentrations $\left(\mu \mathrm{g} \cdot \mathrm{L}^{-1}\right)$ given by the Fluoroprobe ${ }^{\mathrm{TM}}$ for each pigment class, and the total biovolume $\left(\mu m^{3} \cdot L^{-1}\right)$ for each phytoplankton class, i.e. a) the "Browns" associated with the Diatoms, Dinoflagellates and Chrysophyceae (DDC); b) the "Reds" associated with the Cryptophyceae and the PE-rich Cyanobacteria (CRC); c) the "Greens" associated with the Chlorophyceae and Euglenophyceae (CD); d) the "Blue-Greens" associated with the Blue-Green Cyanobacteria (BGC).

\section{Figure 5}

Relation entre les concentrations $\left(\mu \mathrm{g} \cdot \mathrm{L}^{-1}\right)$ en chl a totales obtenues avec la sonde bbe Fluoroprobe ${ }^{\mathrm{TM}}$ pour chaque groupe pigmentaire et le biovolume total pour chaque classe phytoplanctonique, c'est-àdire les « Browns (marrons) " avec les diatomées, dinoflagellées et chrysophycées (DDC); b) les "Reds (rouge) » avec les cryptophycées et les cyanobactéries riches en phycoérythrine (CRC); c) les " Greens (vertes) » avec les chlorophycées et euglénophycées (CD); d) les « Blue-Greens (bleues-vertes) » représentés par les cyanobactéries bleues-vertes (BGC).

measurement of chl a after pigment extraction and the bbe Fluoroprobe ${ }^{\mathrm{TM}}$ used in situ. This had also been observed by Gregor and Maršálek (2004), who revealed an excellent correlation between the total (equivalent) chl a measured by the bbe Fluoroprobe ${ }^{\mathrm{TM}}$, and the chl a determined by spectrophotometry after pigment extraction $(r=0.97, p<0.05$, $n=18)$. Gregor et al. (2005) found much the same relationship ( $r=0.95, p<0.01, n=96)$. However, the spectrofluorometric values (for equivalent chl a) were always lower than spectrophotometric ones (Pinckney et al., 1994), which was probably due to the fact that the bbe Fluoroprobe ${ }^{\mathrm{TM}}$ was originally calibrated on the basis of HPLC analysis, which usually reports lower chl a concentrations than spectrophometric methods, especially if ethanol is used for the extraction process. This is probably due to the presence of other chlorophyll-like pigments that interfere with the spectrophotometric measurements (Meyns et al., 1994; Gregor et al., 2005). In contrast, it has also been shown that the presence of certain accessory pigments, 


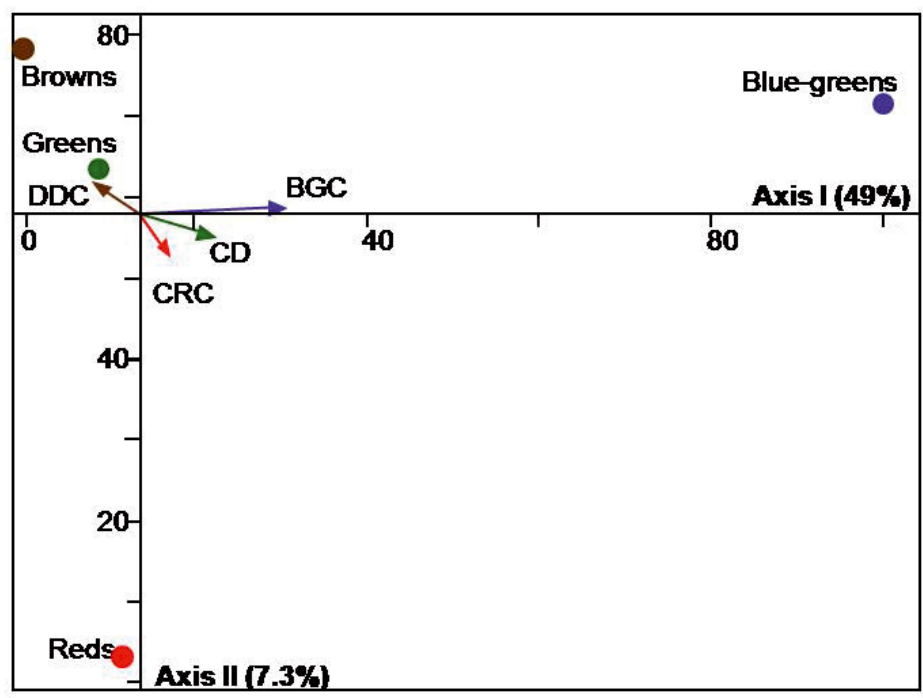

\section{Figure 6}

Canonical correspondence analysis computed from 243 determinations of the total chl a concentrations $\left(\mu \mathrm{g} \cdot \mathrm{L}^{-1}\right)$ given by the Fluoroprobe ${ }^{\mathrm{TM}}$ for each pigment class in relation to the total biovolume $\left(\mu \mathrm{m}^{3} \cdot \mathrm{L}^{-1}\right)$ for each phytoplankton class obtained with the Utermöhl technique. The percentage of variance explained is $56.3 \%$ in the two first axes. The following abbreviations are used in this graph. For the Utermöhl technique: "DDC" corresponds to the sum of biovolumes of the Diatoms, Dinoflagellates and Chrysophyceae, "CRC" to the Cryptophyceae and the PE-rich Cyanobacteria, "CD" to the Chlorophyceae and Euglenophyceae, and "BGC" to the Blue-Green Cyanobacteria. For the Fluoroprobe ${ }^{\mathrm{TM}}$ results: "Browns" corresponds to the chl a concentrations of Diatoms, Dinoflagellates and Chrysophyceae, "Reds" to the Cryptophyceae and the PE-rich Cyanobacteria, "Greens" to the Chlorophyceae and the Desmidiates, and "Blue-Greens" to the Blue-Green Cyanobacteria.

\section{Figure 6}

Analyse canonique des correspondances effectuée à partir de 243 points de mesure de la concentration en chl a obtenue avec la sonde bbe Fluoroprobe ${ }^{T M}$ pour chacun des groupes pigmentaires et le biovolume total mesuré par microscopie. Le pourcentage de variance expliquée est de 56,3 \% pour les deux axes principaux. «DDC » représente la somme des biovolumes des diatomées, dinoflagellées et chrysophycées, « $\mathrm{CRC}$ » celle des cryptophycées et cyanobactéries riches en phycoérythrine, « $C D$ » celle des chlorophycées et euglénophycées, et «BGC » celle des cyanobactéries bleues-vertes. Pour la sonde bbe, « Browns (marrons) » correspond à la concentration en chlorophylle a totale des diatomées, dinoflagellées et chrysophycées, «Reds (rouges) " à celle des cryptophycées et cyanobactéries riches en phycoérythrine, «Greens (vertes) » à celle des chlorophycées et euglénophycées, et « Blue-Greens (bleues-vertes) » à celle des cyanobactéries bleues-vertes.

such as pheophytin, can interfere with the fluorometric measurements and consequently lead to an underestimation of chl a concentrations by producing lower values than spectrophotometric analyses (Pinto et al., 2001). Another explanation for the difference between the two methods lies in what is being measured. Typically, spectrophotometry measures the total chl a concentration, whereas spectrofluorometry estimates chl a for specific algal classes, and consequently does not provide an accurate estimation of all the phytoplankton present in the water column. In addition, the fluorometry-based method with the bbe measured fluorescence, which means that the chl a concentration is estimated from physiologically active cells, whereas spectrophotometry is a measure of absorbance, and is independent of the physiological status of the cells, which may be active, senescent and/or lysed. The physiological status of cells can indeed affect their pigment content and fluorescence (Meeks, 1974; Vörös and Padisák, 1991). Thus, the two methods do not measure exactly the same thing. Furthermore, the accuracy of in vivo fluorometric determination is limited by the quantum efficiency (quanta emitted to quanta absorbed), as well as the species composition, and the physiological status of the phytoplankton. Consequently, spectrophotometry can be expected 
to indicate higher chl a concentrations than spectrofluorometry. However, it remains true that, when evaluating the chlorophyll a present in living cells it is more convenient to measure the fluorescence of the water containing them (Pinto et al., 2001).

\section{> DEPTH-RELATED DIFFERENCES (3, 6 AND 8 M)}

As we have shown, the correlation between the chl a concentrations obtained with the bbe Fluoroprobe $^{\mathrm{TM}}$ and those provided by spectrophotometric analyses were close, and highly significant at 3 and $6 \mathrm{~m}$, whereas the correlation was weaker at $8 \mathrm{~m}$, although still highly significant. This can seem surprising, because fluorescence is known to be significantly inhibited in subsurface layers due to the "quenching" effect of high irradiance on surface waters (Long et al., 1994; Falkowski and Raven, 1997). This phenomenon was identified as a potentially important drawback by Leboulanger et al. (2002), since it could reduce the fluorescence detected for a given population (e.g. Planktothrix rubescens) by up to $40 \%$. This effect is associated with days characterized by high irradiance, and the fact that we did not detect it was probably because the irradiance of the Marne Reservoir was low while we were working there. However, as light transmission is significantly lower at greater depths than on the surface, suspended particles could also explain the weaker relationship found for deeper layers. In fact, the Marne Reservoir is a wind-exposed, shallow water system with a long fetch that leads to water mixing, and sediment particles are likely to be suspended at the bottom of the water column. This phenomenon may induce an increase in water turbidity low in the water column, and affect the scatter of the excitation light from diodes, as well as that of the fluorescence emitted by the phytoplanktonic cells. Using the percentage transmission of the water detected by the bbe with the $710 \mathrm{~nm}$ LED placed opposite to the detector, we observed that the percentage of transmission could fall from $90 \%$ at the surface, to less than $75 \%$ near the bottom sediments. It was difficult to assess whether this could have influenced the intensity of light emitted by the diodes reaching the cells or their fluorescence response, but this was clearly not impossible. Interestingly, Beutler et al. (2002) reported that even when transmission was reduced by $50 \%$, the chl a detected decreased by only $5 \%$, but we can postulate that as their test was done using cultured green alga (Chlorella vulgaris), other species, especially in the field, could behave differently.

\section{$>$ THE EFFICIENCY OF THE FLUOROPROBETM DEPENDS ON THE CONCENTRATION RANGE CONSIDERED}

The closest correlations between the two methods were found for total chl a concentrations ranging from 3.9 to $6.9 \mu \mathrm{g} \cdot \mathrm{L}^{-1}$ and for chl a concentrations below $3.9 \mu \mathrm{g} \cdot \mathrm{L}^{-1}$ which indicates that the Fluoroprobe ${ }^{\mathrm{TM}}$ is likely to be more suitable for detecting the low levels of chl $a$ in the Marne Reservoir. In fact, what we found was that on the contrary, there was no correlation between the two methods for concentrations above $21.6 \mu \mathrm{g} \cdot \mathrm{L}^{-1}$. We are aware, however, that the very small number of points and dynamic range in values for these "high chlorophyll conditions" could drive the significance of the statistical relationships. The underestimation of the chl a level in the context of a high phytoplankton biomass has already been reported, especially when colonial species are present (Gregor and Maršálek, 2004). Optical density, increased by the presence of large amounts of phytoplankton, could severely limit the use of this method. Light emitted by the instrument, or by phytoplankton, can be shaded, scattered or re-absorbed, all of which can all lead to a biased estimate of the quantity of phytoplankton present (Gregor et al., 2005). Another possible reason for the lack of relationship found at high concentrations of chl $a$ is the fact that values for chlorophyll a given by the Fluoroprobe ${ }^{\mathrm{TM}}$ can be affected by the fluorescence of various cDOMs also present in the water. At lower concentrations of chl a particularly, there is no interference between these substances and phytoplankton cells, whereas in the presence of high concentrations of phytoplankton associated with high concentrations of these chemicals, the CDOM fluorescence can be falsely attributed to fluorescence of non-phytoplanktonic origin (Gregor and Maršálek, 2004). It is 
also noteworthy that there were far more measurements below 6.9 than above $21.6 \mu \mathrm{g} \cdot \mathrm{L}^{-1}$ and we cannot completely exclude the possibility that this could have influenced the results, although we believe it was not the case (see Materials and methods).

\section{> THE STRENGTH OF THE RELATIONSHIP BETWEEN BIOVOLUME ESTIMATES AND CHLOROPHYLL A CONCENTRATIONS PROVIDED BY THE BBE FLUOROPROBE ${ }^{\mathrm{TM}}$}

Keeping in mind that pigment content per unit biovolume may vary as a function of physiological state, light exposure history, and the type of phytoplankton present, we found significant relationships between total phytoplankton biovolume estimates and chl a concentrations given by the Fluoroprobe ${ }^{\mathrm{TM}}$, for both the whole dataset and for the spectral groups taken separately. However, the trends differed considerably in the different algal groups. Moreover, the CCA analysis highlighted a close correlation between the two matrices for the "Browns" and the "DDC", the "Reds" and the "CRC", the "Blue-Greens" and the "BGC", but poor correlation between the two matrices for the "Greens" and the "CD".

On the one hand, it is important to remember that an average biovolume was used for all the samples analyzed whatever the sampling date, the station or the depth. However, biovolume can change with season and with depth, just as the chl a content of the phytoplanktonic cells can vary with time and place (Harris, 1986; Tadonléké et al., 1998). Moreover, chl a content can depend on the taxonomic composition. In fact, the difference in the taxonomic composition of phytoplankton can account for most of the variability in the chlorophyll-biovolume relationship, which depends on the life form of the predominant group and its average cell size (Felip and Catalan, 2000). Consequently, it is generally difficult to look for a clear correlation between biovolume and chl a concentrations (Labaugh, 1995) (determined by the standard method or by the bbe Fluororobe ${ }^{\mathrm{TM}}$ ), since these parameters are not strictly related, and because the variation in cell size and chl a content is high not only within divisions, but often even within a given genus during different seasons (Desortová, 1981; Gregor et al., 2005). Finally, the weak relationship between total phytoplankton biovolume, and (equivalent) chl a concentrations can depend on internal cellular factors, such as their physiological status (a large biovolume, but low photosynthesis activity) as well as external factors such as temperature and light conditions (Soohoo et al., 1986; Felip and Catalan, 2000; Staehr et al., 2002), and nutrient availability (Pannard et al., 2007; Twiss and McLeod, 2008). For instance, Beutler et al. (2002) reported that when the culture reached nutrient limitation the fluorescence intensity was $50 \%$ higher (due to changes in the pigment composition of the peripheral antennae).

On the other hand, when the spectral groups associated with phytoplankton classes were taken into consideration, the relationships highlighted a close correlation between the amount of chl $a$ in the "Browns", and the biovolume of diatoms, dinoflagellates and chrysophytes, which is also observed in the CCA analysis between the "Browns" and the DDC. The species that belong to these classes consist mainly of high-biovolume cells that are likely to be detected by the Fluoroprobe ${ }^{\mathrm{TM}}$. Thus, it might be possible that when they are present they may interfere with the detection of other minority communities present. The correlation between the amount of chl a for the "Reds" and the biovolume of cryptophytes and PE-rich cyanobacteria was not as strong, although still significant. PE-rich cyanobacteria were not abundant in our samples, but cryptophytes were. These are flagellated algae that are readily distorted, and so their biovolume can be misestimated when a fixative such as Lugol's solution is added to the samples. Moreover, these algae display a wide range of cell sizes and seasonal shape plasticity. Reynolds (1984) reported a cell volume for Cryptomonas ovata between 1950 and $3750 \mu \mathrm{m}^{3}$, which suggests that the mean biovolume that we calculated for each sample may not have strictly corresponded to the species biovolume of this group throughout both sampling periods. Furthermore, the weak correlation between the amount of chl a for the "Greens" and the biovolume of chlorophytes and euglenophytes, which is confirmed by the inverse correlation of the CCA, can be partly explained by the fact that they aggregate in larger colonies that do not allow the excitation light to penetrate the cells inside the colony. Moreover, Felip 
and Catalan (2000) proposed that there might be a time lag between the change in biovolume and the cell chlorophyll a content. This could explain the weak relationship found for this group. Finally, the weakest relationship was found for the amount of chl a for the "BlueGreens" and the biovolume of blue-green cyanobacteria. This can be explained by the low proportion of cyanobacteria in our samples, which generated many low values. In fact, as only eight chl a concentrations were above $5 \mu \mathrm{g} \cdot \mathrm{L}^{-1}$ and these were associated with biovolumes above $2.5 \times 10^{6} \mu \mathrm{m}^{3} \cdot \mathrm{L}^{-1}$, it would have been difficult to demonstrate a strong relationship. This can partly explain the reason for the contradictory result provided by the CCA for the "Blue-Greens" and the "BGC" that tends to highlight a close relationship between the two matrices for these two groups. In fact, the CCA compares the two matrices, and is less sensitive to a high number of null values. It should also be mentioned that the phycocyanin content per cell in cyanobacteria sometimes varies (Rodriguez et al., 1991; Foy, 1993; Takano et al., 1995). Thus, estimating an average biovolume for colonies and filaments can lead to mistakes that are reflected in the relationship between the biovolume and the chl a content. Finally, as picophytoplankton (which although, on one hand, may represent a small portion of the total biovolume but, on the other hand, may represent a large component of the chl a content) was not considered here, this could also explain the weak relationships observed for some of the groups.

Overall, our results support the proposal that this in situ method can be used to provide quantitative data, whereas microscopic analyses should be used to provide information about dominant species, and provide a way to check the approximately measured ratio between the different algal groups. We can thus recommend the bbe Fluoroprobe ${ }^{\mathrm{TM}}$ as an efficient tool for water quality analysis, bathing water surveillance, and bloom detection in the Marne Reservoir. For cyanobacterial assessment, however, microscopic observations are required, and other systems, such as the bbe AlgaeTorch, Moldaenke, that provides the total chl a concentration and the relative proportion of blue-green cyanobacteria specifically, could be more appropriate.

\section{>CONCLUSION AND PROSPECTS}

The relationships between the different chl a concentrations were fairly close, and these results encouraged us to use the whole dataset provided by the bbe Fluoroprobe ${ }^{\mathrm{TM}}$ from the Marne Reservoir to study the spatial and temporal variability in the phytoplankton dynamics in detail, as illustrated for the "Browns" in Figure 7. This is the aim of a forthcoming study (Rolland et al., unpublished). We have to keep in mind, however, that the results obtained for each class compared with biovolume estimates remain somewhat problematic, especially for the blue-green cyanobacteria, a group of major interest in the context of water quality surveys. It remains true that we can conclude from our findings that the Fluoroprobe ${ }^{T M}$ offers a very efficient way of monitoring phytoplankton in reservoirs, especially for water managers and researchers who require quick and accurate methods. This sensor can serve as a good screening tool for phytoplankton quantification, as well as for preliminary taxonomic identification, and it could be particularly advantageous for the routine monitoring of water quality, at any depth where detailed microscopic analyses are not necessary or difficult. The two methods used here are still complementary rather than mutually exclusive, and can be used to provide reliable data for device validation with regard to the ecosystem studied. In the future, water managers will increasingly require fast and effective diagnostic methods, and the bbe Fluoroprobe ${ }^{\mathrm{TM}}$ and related devices will be of great interest, provided that the findings are critically assessed and checked for accuracy. There are numerous possible applications: monitoring blue or red cyanobacteria in drinking water, control testing bathing water for harmful algal blooms, limnological research, supervision of aquaculture systems, early warning systems, and, since it can also be used to provide continuous measurements along the water column, avoiding missing a local phenomenon (typically the concentration of a population in a thin layer) and/or rapid changes in some localities (at a specific depth or recruitment from the sediments). 

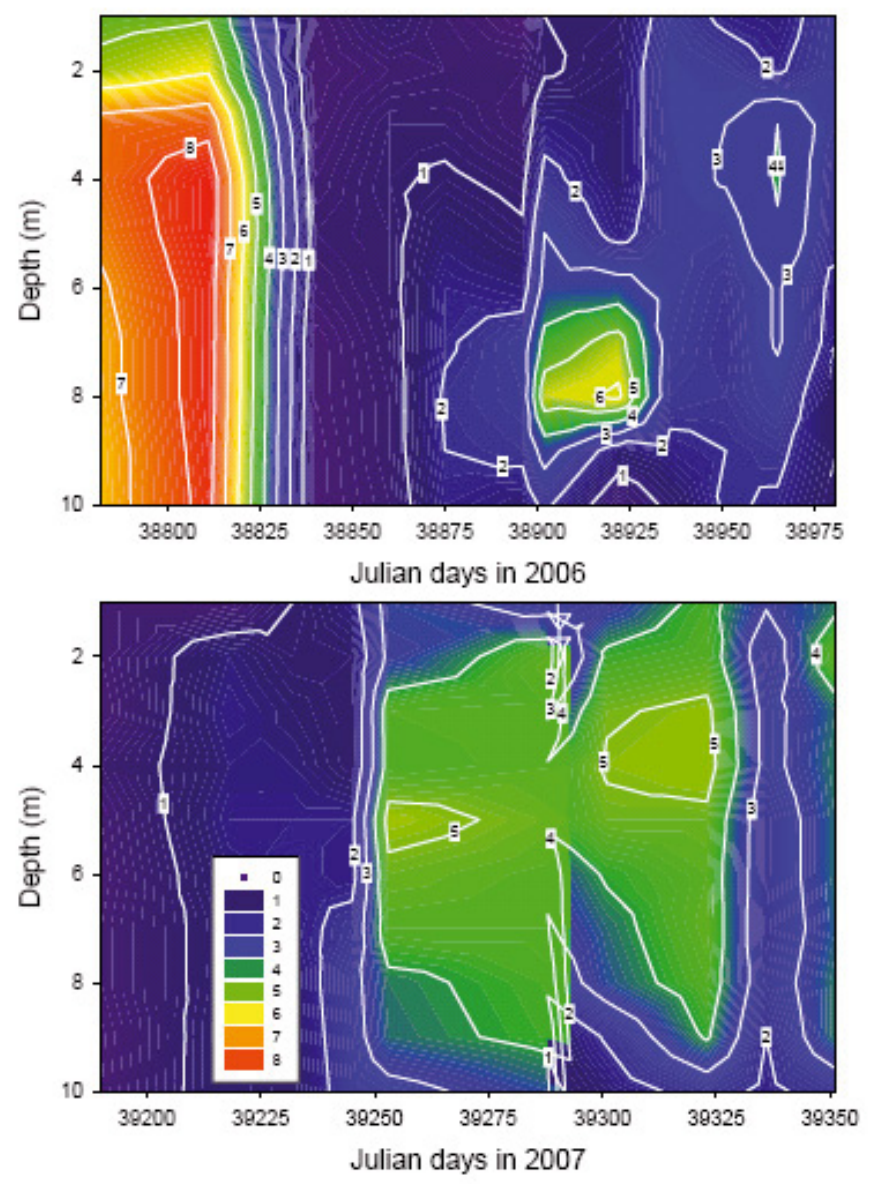

\section{Figure 7}

Spatio-temporal dynamics of the "Browns" determined with the bbe Fluoroprobe ${ }^{\mathrm{TM}}$ over the two sampling years (2006-2007), at the station $\mathrm{H}$, between the surface and $10 \mathrm{~m}$.

\section{Figure 7}

Dynamique spatio-temporelle des «Browns (marrons)" telle qu'obtenue avec la sonde bbe Fluoroprobe ${ }^{\mathrm{TM}}$ sur toute la période 2006-2007 étudiée, à la station $\mathrm{H}$, entre la surface et $10 \mathrm{~m}$ de profondeur.

\section{ACKNOWLEDGEMENTS}

This work was supported by the IIBRBS (Institut Interdépartemental des Barrages du Bassin de la Seine), a CIFRE contract granted to AR from ANRT (Agence Nationale de la Recherche et de la Technologie), and the Seine-Normandie Water Agency. Jean-Claude Druart, Gérard Beaudoin and Yannik Guillemin are thanked for their help in the sampling of the Marne Reservoir. We are grateful to Christophe Leboulanger (IRD, Montpellier) for his help when preparing the revised version. The bbe Fluroprobe ${ }^{\mathrm{TM}}$ was purchased by the "Environment" Division of IIBRBS. The English has been checked by a native English-speaking scientific editor.

\section{REFERENCES}

AFNOR, 1999. Water Quality - Determination of Chlorophyll a and of a phaeopigments index - Molecular Absorption Spectrometric Method, NF T90-117.

AFNOR, 2006. Water Quality - Guidance standard on the enumeration of phytoplankton using inverted microscopy (Utermöhl technique), NF EN 15204. 
Allee R.J. and Johnson J.E., 1999. Use of satellite imagery to estimate surface chlorophyll a and Secchi disc depth of Full Shoals Reservoir, Arkansas, USA. Int. J. Remote Sens., 20, 1057-1072.

Anneville O., Ginot V., Druart J.-C. and Angeli N., 2002. Long term study (1974-1998) of seasonal changes in the phytoplankton in Lake Geneva: a multiple table approach. J. Plankton Res., 24, 993-1007.

Beutler M., Wilshire K.H., Meyer B., Moldaenke C., Lüring C., Meyerhöfer M., Hansen H.P. and Dau $\mathrm{H}$., 2002. A fluorometric method for the differentiation of algal populations in vivo and in situ. Photosynth. Res., 72, 39-53.

Brettum P., 1989. Algen als Indikatoren für die Gewässerqualität in norwegischen Binnenseen. Norsk Institutt for Vannforskning, NIVA, 2344, 1-111.

CIPEL, 1984. Le Léman : Synthèse des travaux de la Commission internationale pour la protection des eaux du Léman contre la pollution 1957-1982, Presses de l'imprimerie de l'ère nouvelle, Lausanne.

De Bortoli J. and Argillier C., 2008. Définition des conditions de référence et des limites des classes d'état sur la base d'une approche pressions/impacts - Plans d'eau - Paramètre Chlorophylle $a$. Rapport CEMAGREF.

Desiderio R.A., Moore C., Lantz C. and Cowles T.J., 1997. Multiple excitation fluorometer for in situ oceanographic applications. Applied Optics, 36, 1289-1296.

Desortová B., 1981. Relationship between chlorophyll a concentration and phytoplankton biomass in several reservoirs in Czechloslovakia. Int. Rev. gesamten Hydrobiol., 66, 153-169.

Dokulil M.T., Teubner K. and Greisberger S., 2005. Typenspezifische Referenzbedingungen für die integrierende Bewertung des ökologischen Zustandes stehender Gewässer Österreichs gemäß der EU-Wasserrahmenrichtlinie. Modul 1: Die Bewertung der Phytoplankton struktur nach dem Brettum-Index. Projekstudie Phase 3, Abschlussbericht. Im Auftrag des Bundesministeriums für Land- und Forstwirtschaft, Umwelt und Wasserwirtschaft, Wien.

European Commission, 2008. Commission Decision of 30 October 2008 establishing, pursuant to Directive 2000/60/EC of the European Parliament and of the Council, the values of the Member State monitoring system classifications as a result of the intercalibration exercise. Official Journal of the European Communities, 332, 20-44.

European Parliament, 2000. Directive 2000/60/EC of the European Parliament and of the Council of 23 October 2000 establishing a Framework for Community action in the field of water policy. Official Journal of the European Communities, 327, 1-72.

Falkowski P.G. and Raven J.A., 1997. Aquatic Photosynthesis, Blackwell Sciences, Oxford.

Felip M. and Catalan J., 2000. The relationship between phytoplankton biovolume and chlorophyll in a deep oligotrophic lake: decoupling in their spatial and temporal maxima. J. Plankton Res., 22, 91-105.

Foy R.H., 1993. The phycocyanin to chlorophyll a ratio and other cell components as indicators of nutrient limitation in 2 planktonic cyanobacteria subjected to low-light exposures. J. Plankton Res., 15, 1263-1276.

Gregor J. and Maršálek B., 2004. Freshwater phytoplankton quantification by chlorophyll a: a comparative study of in vitro, in vivo and in situ methods. Water Res., 38, 517-522.

Gregor J., Geriš R., Maršálek B., Hetesá J. and Marvan P., 2005. In situ quantification of phytoplankton in reservoirs using a submersible spectrofluorometer. Hydrobiologia, 548, 141-151.

Harris G.P., 1986. Phytoplankton Ecology: Structure, Function and Fluctuation, 1st edition, Chapman \& Hall, London.

Higgs E.S., 1997. What is Good Ecological Restoration? Conserv. Biol., 11, 338-348.

Hillebrand H., Dürselen C.D., Kieschtel D., Zohary T. and Pollingher U., 1999. Biovolume calculation for pelagic and benthic microalgae. J. Phycol., 35, 403-424.

Jacquet S., Briand J.F., Leboulanger C., Avois-Jacquet C., Paolini G., Oberhaus L., Tassin B., VinçonLeite B., Druart J.C., Anneville O. and Humbert J.F., 2005. The proliferation of the toxic cyanobacterium Planktothrix rubescens following restoration of the largest natural French lake (Lac du Bourget). Harmful Algae, 4, 651-672.

Jacquet S., Paolini G., Lazzarotto J., Girel C., Druart J.C., Perga M., Berdjeb L., Kerrien S., Humbert J.F., Domaizon I., Perney P. and Laine L., 2008. Suivi de la qualité des eaux du lac du Bourget pour l'année 2007, Rapport CISALB. 
Labaugh J.W., 1995. Relation of algal biovolume to chlorophyll-a in selected lakes and wetlands in the North Central United States. Can. J. Fish. Aquat. Sci., 52, 416-424.

Leboulanger C., Dorigo U., Jacquet S., Le Berre B., Paolini G. and Humbert J.F., 2002. Application of a submersible spectrofluorometer for rapid monitoring of freshwater cyanobacterial blooms: a case study. Aquat. Microb. Ecol., 30, 83-89.

Long S.P., Humphries S. and Falkowski P.G., 1994. Photoinhibition of photosynthesis in nature. Annu. Rev. Plant Physiol. Plant Mol. Biol., 45, 633-662.

Lorenzen C.J., 1967. Determination of chlorophyll and pheopigments by spectrophotometric equations. Limnol. Oceanog., 12, 343-346.

McCune B. and Mefford J., 2006. PC-ORD - Multivariate Analysis of Ecological Data, Version 5.18, MjM Software, Gleneden Beach, Oregon.

Meeks J.C., 1974. Chlorophylls. In: Stewart W.D.P. (ed.), Algal Physiology and Biochemistry, Blackwell Scientific Publications, Oxford, 161-175.

Meyns S., Illi R. and Ribi B., 1994. Comparison of chlorophyll-a analysis by HPLC and spectrophotometry: Where do the differences come from? Arch. Hydrobiol., 132, 129-139.

Millie D.F., Fahnenstiel G.L., Carrick H.J., Lohrenz S.E. and Schofield O.M.E., 2002. Phytoplankton pigments in coastal Lake Michigan: distributions during the spring isothermal period and relation with episodic sediment resuspension. J. Phycol., 38, 639-648.

Moline M.A. and Prezelin B.B., 1997. High-resolution time-series data for in situ carbon fixation at a Palmer LTER site and its implications for modeling primary production in the Southern Ocean. Polar Biol., 17, 39-53.

Moline M.A., Prezelin B.B. and Schofield O., 1997a. Palmer LTER: Stable interannual successional patterns of phytoplankton communities in the coastal waters off Palmer Station. Antarctic Journal of the United States, 32, 151-153.

Moline M.A., Prezelin B.B., Schofield O. and Smith R.C., 1997b. Temporal dynamics of coastal Antarctic phytoplankton: Environmental driving forces and impact of a 1991-1992 summer diatom bloom on the nutrient regimes. In: Battaglia B., Valencia J. and Walton D.W.H. (eds.), Antarctic communities, Cambridge University Press, Cambridge, 67-72.

Pannard A., Bormans M., Lefebvre S., Claquin P. and Lagadeuc Y., 2007. Phytoplankton size distribution and community structure: influence of nutrient input and sedimentary loss. J. Plankton Res., 29, 583-598.

Pinckney J., Papa R. and Zingmark R., 1994. Comparison of high-performance liquid-chromatographic, spectrophotometric and fluorometric methods for determining chlorophyll a concentrations in estuarine sediments. J. Microbiol. Methods, 19, 59-66.

Pinto A.M.F., Von Sperling E. and Moreira R.M., 2001. Chlorophyll-a determination via continuous measurement of plankton fluorescence: Methodology development. Water Res., 35, 3977-3981.

Reynolds C.S., 1984. The ecology of freshwater phytoplankton, Cambridge University Press, Cambridge.

Reynolds C.S., Huszar V., Kruk C., Naselli-Flores L. and Melo S., 2002. Towards a functional classification of the freshwater phytoplankton. J. Plankton Res., 24, 417-428.

Rodriguez H., Rivas J., Guerrero M.G. and Losada M., 1991. Enhancement of phycobiliprotein production in nitrogen-fixing cyanoabcteria. J. Biotechnol., 20, 263-270.

Rolland A. and Jacquet S., 2010. Classification de l'état écologique du réservoir Marne via l'utilisation de 3 métriques : chlorophylle a, indice planctonique lacustre et phosphore total. Hydroécol. Appl., 17, DOI: 10.1051/hydroecol/2010003.

Smayda T.J., 1978. From phytoplankters to biomass. In: Sournia A. (ed.), Phytoplankton Manual, Unesco Paris, 273-279.

Sommer U., 1983. Nutrient competition between phytoplankton species in multispecies chemostat experiments. Arch. Hybrobiol., 96, 399-416.

Soohoo J.B., Kiefer D.A., Collins D.J. and McDermid I.S., 1986. In vivo fluorescence excitation and absorption spectra of marine phytoplankton. J. Plankton Res., 8, 197-214.

Staehr P.A., Henricksen P. and Markager S., 2002. Photoacclimation of four marine phytoplankton species to irradiance and nutrient availability. Mar. Ecol. Progr. Ser., 238, 47-59.

Tadonléké R.D., Jugnia L.B., Sime-Ngando T., Zebaze S. and Nola M., 1998. Short-term vertical distribution of phytoplankton populations in a shallow tropical lake (Lake Municipal, Yaounde, Cameroon). Arch. Hydrobiol., 143, 469-485. 
Takano H., Arai T., Hirano M. and Matsunaga T., 1995. Effects of intensity and quality of light on phycocyanin production by a marine cyanobacterium Synechococcus sp. NKBG-042902. Appl. Microbiol. Biotechnol., 43, 1014-1018.

ter Braak C.J.F., 1986. Canonical correspondence analysis: A new eigenfactor technique for multivariate direct gradient analysis. Ecology, 67, 1167-1179.

ter Braak C.J.F., 1987. The analysis of vegetation-environment relationships by canonical correspondence analysis. Vegetatio, 64, 69-77.

Thyssen M., Mathieu D., Garcia N. and Denis M., 2008. Short-term variation of phytoplankton assemblages in Mediterranean coastal waters recorded with an automated submerged cytometer. J. Plankton Res., 30, 1027-1040.

Tilmann D., Kiesling R., Sterner R., Kilham S. and Johnson F.A., 1986. Green, blue-green and diatom algae: taxonomic differences in competitive ability for phosphorus, silicon and nitrogen. Arch. Hydrobiol., 106, 473-485.

Trees C.C., Clark D.K., Bidigare R.R., Ondrusek M.E. and Mueller J.L., 2000. Accessory pigments versus chlorophyll a concentrations within the euphotic zone: A ubiquitous relationship. Limnol. Oceanog., 45, 1130-1143.

Twiss M. and McLeod I., 2008. Phytoplankton community assessment in eight Lake Ontario tributaries made using fluorimetric methods. Aquat. Ecosyst. Health Manag., 11, 422-431.

Utermöhl H., 1958. Zur Vervollkommung der quantitativen Phytoplankton-Methodik. Mitteillungen der Internationalen Vereinigung für Limnologie, 9, 1-38.

Vollenweider R.A. and Kerekes J., 1982. Eutrophication of waters. Monitoring, assessment and control. OECD Cooperative Programme on monitoring of inland waters (Eutrophication control), Environment Directorate, OECD, Paris.

Vörös L. and Padisák J., 1991. Phytoplankton biomass and chlorophyll a in some shallow lakes in central Europe. Hydrobiologia, 215, 111-119.

Wetzel R.G. and Likens G.E., 2000. Limnological Analyses, 3rd edition, Springer, London.

Wolfram G., Dokulil M.T., Pall K., Reichmann M., Schulz L., Argillier C., de Bortoli J., Martinez P.-J., Rioury C., Hoehn E., Riedmüller U., Schaumburg J., Stelzer D., Buzzi F., Dalmi A., Morabito G., Marchetto A., Remec-Rekar Š. and Urbanic G., 2007. Intercalibration Exercise, Technical Report + Annexes, Alpine GIG (Lakes), Vienna - Ispra.

Wright S.W. and Jeffrey S.W., 1987. Fucoxanthin pigment markers of marine phytoplankton analysed by HPLC and HPTLC. Mar. Ecol. Progr. Ser., 38, 259-266.

Yentsch C.S. and Yentsch C.M., 1979. Fluorescence spectral signatures: The characterization of phytoplankton populations by the use of excitation and emission spectra. J. Mar. Res., 37, 471-483. 